International Journal of Agriculture, Environment and Bioresearch

Vol. 5, No. 02; 2020

ISSN: $2456-8643$

\title{
STUDY OF THE USE OF HYDROPONICS FODDER BARLEY INGOAT FARMING AS AN ALTERNATIVE AGAINST OVERGRAZING OF THE ARGANERAE IN THE REGION SOUSSMASSA (SOUTHERN MOROCCO)
}

\author{
Samir BARI ${ }^{1,2}$, Abdessamad HIKAMAT ${ }^{1}$, Hasna MANNAS ${ }^{2}$, Jawad OUMALIK ${ }^{3}$, Leila ABOUDLOU ${ }^{1}$ and \\ Abderrazak KAAYA ${ }^{1}$ \\ ${ }^{1}$ BioEnvironment, Health and Bioresources Team, Faculty of Sciences, University Ibn Zohr, Agadir, Morocco \\ ${ }^{2}$ Regional Office for Agricultural Development of Souss Massa, Agadir, Morocco. \\ ${ }^{3}$ National Association for Sheep and Goat Breeders, Morocco (ANOC)
}

https://doi.org/10.35410/IJAEB.2020.5499

\begin{abstract}
The goat herd of the Souss Massa region, of which the arganerae is the preferred area, accounts for $16 \%$ of all goats nationally. This herd benefits from this species, which is the only food refuge for local and huge herds from our Saharan provinces. This situation has raised alarm bells in favour of the argan tree and an awareness not only for its protection as a natural heritage, but also as an economic resource to be rehabilitated.

Our study is part of the protection of argan trees and aims to study the use of hydroponic technologies that are proving particularly important in arid and semi-arid regions. We have conducted this research on the use of hydroponic fodder and on the zootechnical performance of goats. It carried out in the region of Imssouane (Agadir Idaoutanane Prefecture) and consists in assessing the effect of the introduction of hydroponic fodder into the food ration and growth performance of the goat herd. To do this, lots of 78 goats were followed during a feeding test over a 6-month period. This follow-up reveals that hydroponic barley is a serious alternative for feeding goats in the region and contributes to significantly improving the zootechnical performance of the goat herd
\end{abstract}

Keywords: Arganerie, Caprin, Imssouane, Hydroponics Barley, Zootechnical performance.

\section{INTRODUCTION}

Farming small ruminants is one of the main activities practiced by people in the rural areas all over the world, Morocco included. According to (MAPM, 2014) statistics, the numbers of sheep and goats counts around24,6 million heads, of which goat represent 5.6million heads. The goat population is characterized by a good adaptation to local climatic conditions, and it is mostly concentrated in mountainous areas and degraded rangeland. Moreover, it constitutes an important economic activity and a source of income for the population (MAPM, 2012).

In these mountainous areas, the goat population is raised mainly for meat production (MAPM, 2012). The Souss-Massa plain in the southern part of the country suffers from a permanent deficiency in fodder resources. Consequently, it severely impedes the development of livestock 
production, especially that of goats(Lafdaili M.,2014). In this region, farms are of the extensive or semi-extensive type, which heavily depends on natural pastures. This degrading of plain is due to various reasons, which could be summed up as follows: unfavorable climactic conditions, socio-economic changes, and the deterioration of the grazing land, which remain the principal source of livestock survival. These areas have been reported to have lost widespread amount of vegetation cover as a result of overgrazing and frequent droughts (Bourbouz et al., 2005). It is therefore evident that the current rangeland does not provide sufficient animal feed. This situation is exacerbated during the dry season, when the quantitative nutritional value the rangeland is drastically reduced. The goats in the Argan tree areas as their farming zone account for $16 \%$ of the goat herd nationally (ORMVA/MS, 2015). the Argan tree zones represent the main fodder source during periods of drought(El Aich et al, 2005). Nowadays, multiple parties sound the alarm calling for the protection of this natural heritage.

From this perspective, the cultivation above ground of fodder plants, such as barley production via the hydroponic technique could be a solution to produce a sustainable and ecological food for livestock to meet the growing needs of the livestock. This could improve farmers' incomes, allow them to settle down and dissuade them from abandoning their activities (Carillo et al, 2013). This culture makes it possible to produce sustainable and good quality fodder. Hydroponic fodderis appreciated by animals and promotes the improvement of their productive capacities (LopezAguilar et al, 2009) and reproductive (Rodriguez Muela et al, 2002) performances.

This work is a continuation of the study undertaken by Bari et al. (2020) to determine the effect of the introduction of Green Hydroponic Fodder to the tune of $30 \%$ of the theoretical requirement of forage in the daily ration, on the consumption and performance of lambs. This study shows higher growth performance in the Test lot.Moreover, the study conducted by Barid and Al. in 2019 seeks to demonstrate the impact of this new process, (called hydroponic green fodder) on the financial structure and performance of a cooperative.

The objective of our work is to study the effect of hydroponic barley (HB) feeding on the productive performance of goats, in the territorial locality of Imssouane, Agadir in the Souss Massa region.

\section{MATERIALS AND METHODS \\ Study area}

The territorial commune of Imssouane is located in West Central Morocco $100 \mathrm{~km}$ north of Agadir, 946.44' degrees West longitude and $30^{\circ}$ 50.46'north latitude. This commune is characterized by an arid to semi-arid climate (Figure 1). 


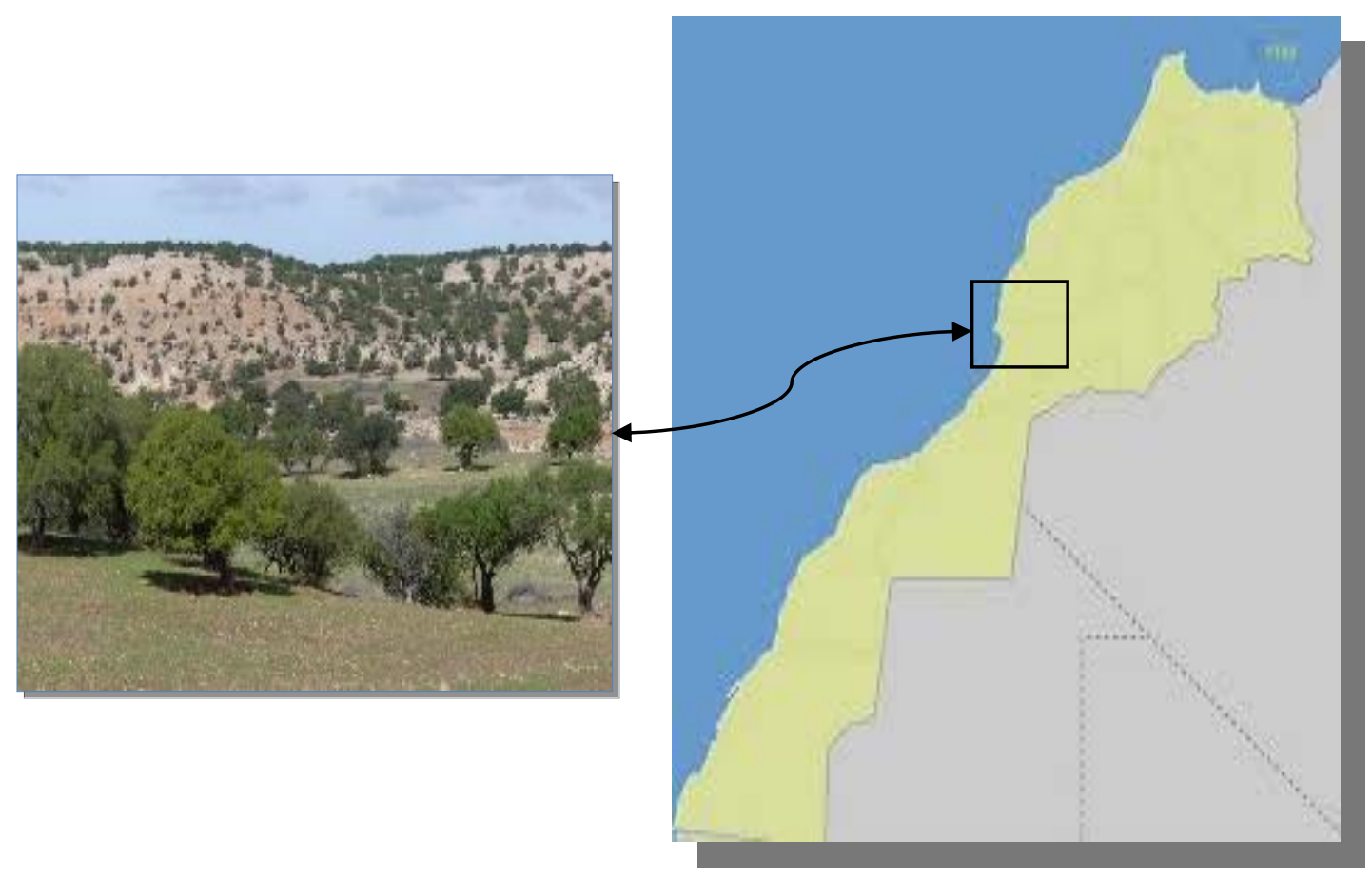

Figure 1. Geographical location of the study site

\section{Rainfall}

The study deals with six successive agricultural campaigns (years 2013, 2014, 2015, 2016, 2017 and 2018) different in terms of rainfall (Figure 2). The data used originate from the Tamrimeteorological station. We were provided with these data by Regional Office for Agricultural Development of Souss Massa (ORMVA/SM).

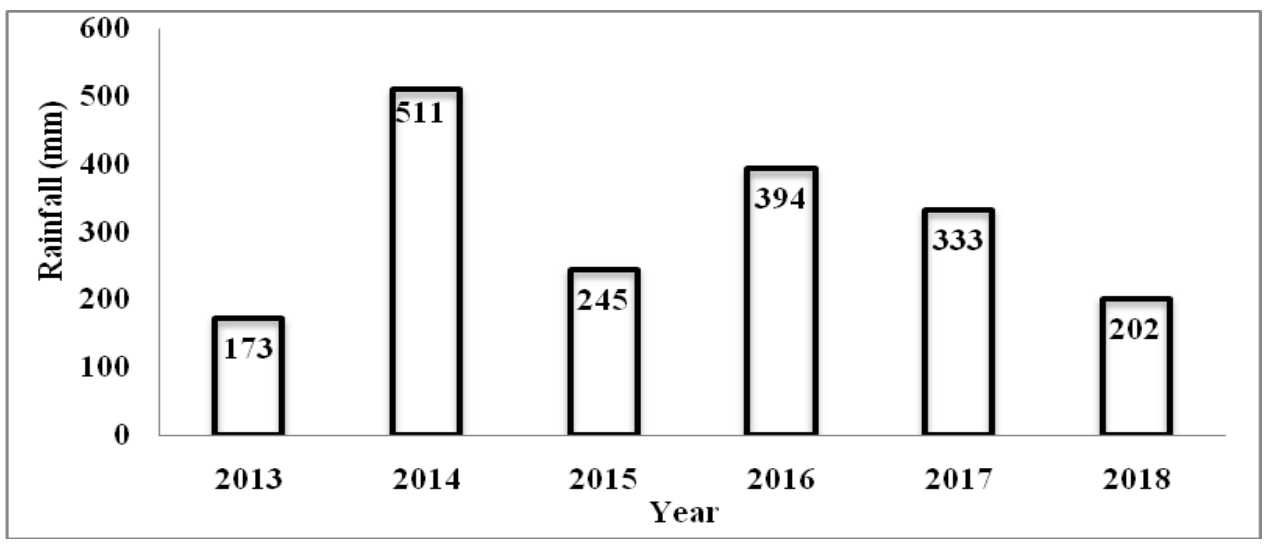

Figure 2: Evolution of average precipitation (mm) in yearSource (ORMVA / SM, 2013-2018) 


\section{Feed balance}

We have established a comparison between the feeding (food) requirements to which we shall refer from now on as Feed Unit (FU) of the livestock and the energy supply of the fodder to assess the level of the balance sheet and the coverage rate of the needs of the livestock at the level of the study area.

\section{Production of Hydroponic Barley fodder(Figure 3)}

The used barley seeds wereinitially cleaned, and disinfected with Sodium Hypochlorite (1 ml /l). Then they were soaked in tap water for 16 to 18 hours, and were eventually distributed over trays, with a seed rate density of $7 \mathrm{Kg} / \mathrm{m}^{2}$. The culture was produced in hydroponic unit (Model E-12-TX-FV) with an area of $100 \mathrm{~m}^{2}$. Conditions inside the chamber were set to get a range ofworking temperature reaching $18 \pm 1.5^{\circ} \mathrm{C}$. Besides, a relative humidity was adjusted at about $60-100 \%$ with a LED Lighting, which provided 30W during 12 hours of daily light. It was equipped with a solar power system (260/24V polycrystalline solar panel (48pcs) (plomo-acido battery ( 24 pcs) OPzS with liquid electrolyte).A technology that allowed for an autonomy of 72 hours. The culture was irrigated by immersion twice a day ( $2 \pm 0.11$ / Kg Raw Material), and the harvest was carried out at the seedling stage at $7 \pm 1$ day. The generally observed yield was 6.01 $\pm 0.10 \mathrm{Kg}$ of green fodder produced per $\mathrm{Kg}$ of dry germinated grain at $12-13.5 \%$ dry material.

Figure 3: Hydroponic barley production unit

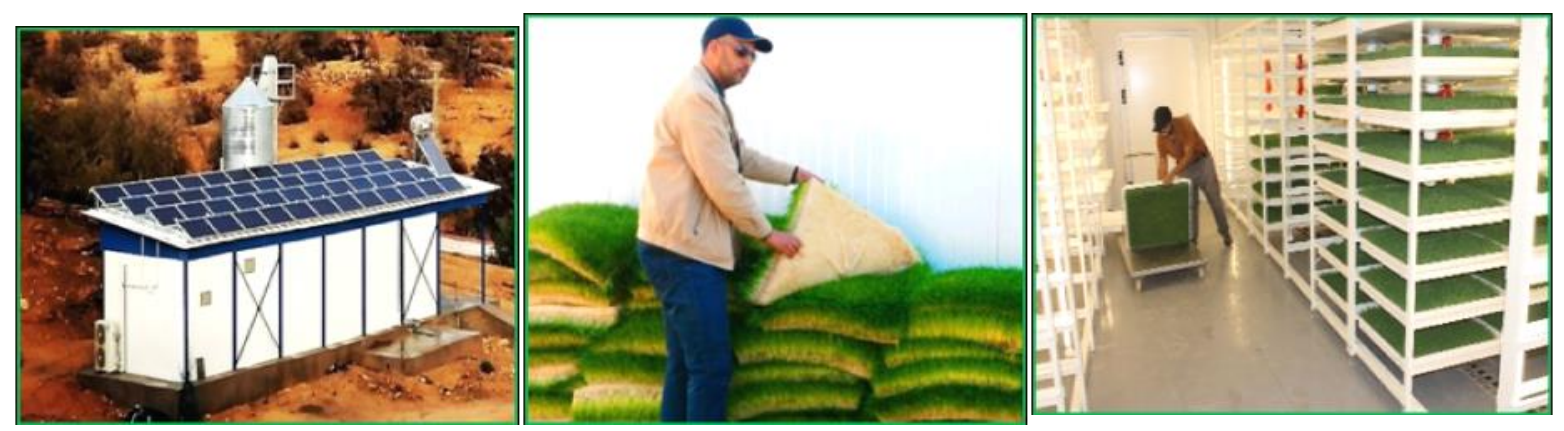


Vol. 5, No. 02; 2020

ISSN: $2456-8643$

\section{Experimental animals}

This study was carried out to assess whether Hydroponic barley fodder can be a beneficial supplement in fodder for goat farming. The purpose of this test was to determine whether the introduction of Hydroponic barley into the ration has an effect on consumption and zootechnical results. The age of the animals observed ranged from 2 months to 4 years with an average weight varied from 7 to $52 \mathrm{Kg}$. A total of two batches of 78 goatling were followed during the feeding process over a period of 6 months. The first group was made up of 78 subjects which benefited from additional Hydroponic barley fodder, and the second group was made up of 78 controlled subjects. The liveweight of the animal was determined after weighing the animal with a $100 \mathrm{Kg}$ weighing scale, with a 200 grams accuracy. This weighing wascompleted on an empty stomach and in non-pregnant state.

\section{Statistical analysis}

The data were entered into Excel 5.0 software.This latter made it possible to process the results at an average \pm standard deviation. The data collected were subjected to ANOVA analysis of variance for all the studied parameters using the software $\mathrm{R} v$ 3.2.5.

\section{RESULTS AND DISCUSSION}

The evolution of the fodder balance covering this particular zone of studies demonstrates a certain persistence of its deficit. In fact, all studied cases of agricultural companies from 2013 to 2018 revealed that all of these companies were in great fodder balance deficit.

A comparison of the livestock needs and the available fodder with the studied zone shows an average yearly deficit of $2,1 \times 10^{6} \mathrm{UF}$; The fodder inflows barely rise to a medium level reaching $3.30 \times 10^{7} \mathrm{UF}$, be it an average coverage rate of $29 \%$. This result ina multitude of constraints that are likely to undermine the development sustainability of agricultural production systems, including: very low rainfall degrees, cyclical drought, and an acute scarcity of water resources.

To compensate for food shortages of goat livestock, and to allow for an improvement in fodder inflows, cattle raisers feel compelled to refrain from grazing on argan trees, and resort to the purchase of concentrated aliment at exorbitant prices. Given these conditions, having recourse to hydroponic techniques, precisely hydroponic barley production which proves to be a useful proceeding. This technique represents a viable alternative which aims to secure the production of local fodder. This fodder is expected to ensure a good quality, low price, and a year-long available fodder, irrespective of any climatic risk. 


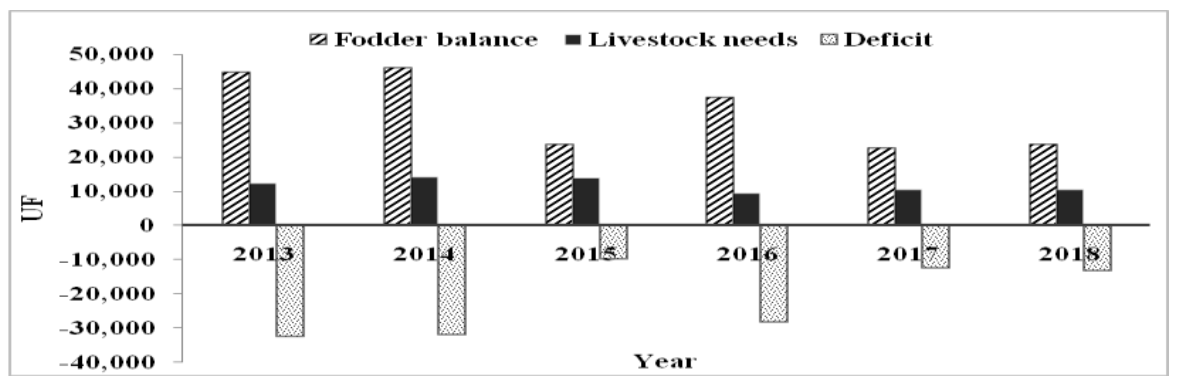

Figure 4: Evolution of the fodder balance in covered zones between the period 2013-2018

The weighing's results of the goat livestock generated based on the criterion of age (Figure 5) attest to a steady increase in growth rates among animals that have benefited from hydroponic barley complements, in comparison to other animal kinds (hereinafter referred to as witness) such as increase varies in correspondence to factors of sex and age of studied animals.

In this period and during a period of 2 to 4 months, the growth rate of males exceeded $30 \%$, more than the growth rate of animals that did not have access to hydroponic barley and scored a growth average of $68 \mathrm{~g}$ per day. During the period lasting from 4 to 6 months the growth rate exceeded more than $36 \%$ in comparison to animals which did not benefit from hydroponic barley, with a $62 \mathrm{~g}$ per day based on a Average daily gain order.
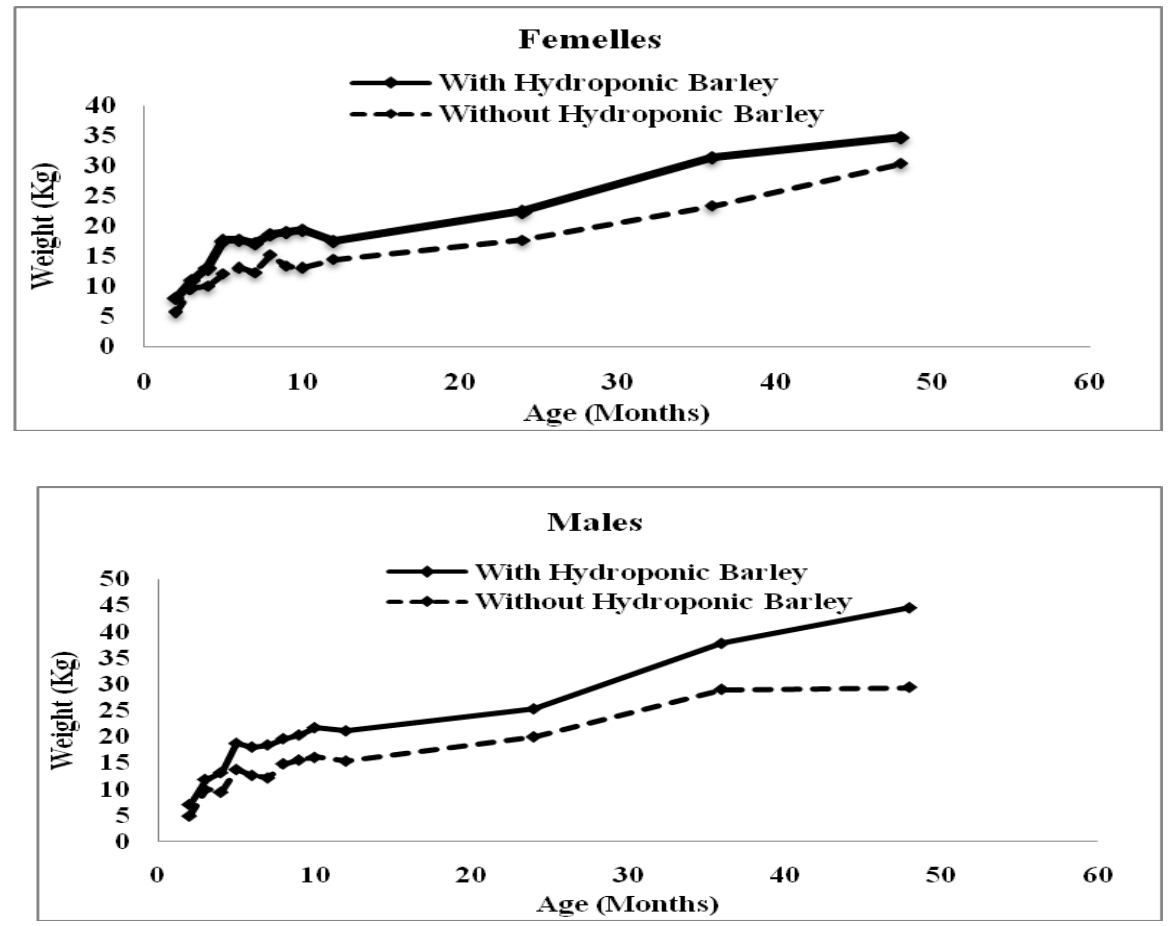

Figure 5: Curves of goat growth with correspondence to consumption or lack thereof of Hydroponic Barely 
As for females, the growth rate was more than $27 \%$ over a period varying between 2 to 6 months, compared to that of animals that did not have access to hydroponic barley, with a Average daily gain reaching $30 \mathrm{~g}$ per day. For the period lasting from 4 to 6 months, we observe a $38 \%$ higher growth rate compared to that of animals which did not consume hydroponic barley with a Average daily gain nearing $26 \mathrm{~g}$ per day (Table 1 ). An analysis of the variance index confirms these data. The difference of weight between our witness and green hydroponic fodder beneficiary animals seems significantly higher $(\mathrm{P}<0.05)$. Besides, the generated results show that increasing figures in case of males $(\mathrm{P}<0.05)$ more than that of females. (Table 2$)$

Table 1:Comparison of goats weight based on sex, age, and consumption or lack thereof of Hydroponic Barely HB

\begin{tabular}{|c|c|c|c|c|}
\hline $\begin{array}{l}\text { Hydroponic } \\
\text { Barley }\end{array}$ & Sex & Age(Months) & $\begin{array}{l}\text { Averageweig } \\
\text { ht }(\mathrm{Kg})\end{array}$ & $\begin{array}{l}\text { Average daily } \\
\text { gain }(\mathrm{g} / \mathrm{j})\end{array}$ \\
\hline \multirow{10}{*}{ With } & \multirow{5}{*}{ Male } & 2 to 4 & 10,6 & 68 \\
\hline & & 4 to 6 & 16,6 & 62 \\
\hline & & 6 to 12 & 19,9 & 41 \\
\hline & & 12 to 36 & 28 & 93 \\
\hline & & 36 to 48 & 41,2 & 78 \\
\hline & \multirow{5}{*}{$\mathrm{e}^{\text {Femal }}$} & 2 to 4 & 10,6 & 28 \\
\hline & & 4 to 6 & 16,1 & 26,1 \\
\hline & & 6 to 12 & 18,3 & 50 \\
\hline & & 12 to 36 & 23,7 & 78 \\
\hline & & 36 to 48 & 33,1 & 75 \\
\hline \multirow{6}{*}{ Without } & \multirow{5}{*}{ Male } & 2 to 4 & 8,1 & 50 \\
\hline & & 4 to 6 & 12 & 48 \\
\hline & & 6 to 12 & 14,5 & 17 \\
\hline & & 12 to 36 & 21,5 & 75 \\
\hline & & 36 to 48 & 29,2 & 50 \\
\hline & Femal & 2 to 4 & 8,3 & 24 \\
\hline
\end{tabular}




\begin{tabular}{|l|l|l|l|l|}
\hline \multirow{3}{*}{} & e & 4 to 6 & 11,6 & 17,2 \\
\cline { 3 - 5 } & 6 to 12 & 13,5 & 12,2 \\
\hline \multirow{5}{*}{} & 12 to 36 & 18,4 & 49,4 \\
\hline & 36 to 48 & 26,8 & 39 \\
\hline
\end{tabular}

Table 2: Results of variance analysis

\begin{tabular}{|l|l|l|l|l|}
\cline { 2 - 5 } & Sum Sq & Df & F value & $\operatorname{Pr}(>\mathrm{F})$ \\
\hline Age & 8444,6 & 12 & 48,4644 & $2,210^{-16}$ \\
\hline Sex & 114,2 & 1 & 7,8668 & 0,00601 \\
\hline ComplementwithHB & 986,1 & 1 & 67,9108 & $5,4710^{-13}$ \\
\hline Age: Sex & 131,8 & 12 & 0,7561 & 0,69 \\
\hline Age: HB & 182,7 & 12 & 1,0487 & 0,41 \\
\hline Sex: HB & 14,2 & 1 & 0,9789 & 0,32 \\
\hline Age: Sex: HB & 83,4 & 12 & 0,4788 & 0,92 \\
\hline
\end{tabular}

The results of the analysis of goats' growth performances of the two cohorts show that this food complement influences the growth parameters of these animals (Table 1).This great performance of the cohorts at different ages as well as the average daily gain of animals provided with hydroponic fodder may be explained by the capacity of these food complement to provide necessary nutrients. The importance of this fodder lies in its great nutritional values. Its richness in amino-acids, vitamins, enzymes, and solvable carbohydrates leads to a smooth processing of starch, and lipids of grain during the germination process (Lorenz et D'Appalonia, 1989; Chavan et Kadam, 1989). In fact, during this latter, the rate of dry material becomes weaker(12-14\%) for reasons of growth and respiration of the plant (Cuddeford, 1989) as well as the mobilization of the grain reserves leading to the growth of its roots increase significantly the cellulose levels, ADG and NDF (Bhise et al., 1988). This overlaps with Naik et al., (2014) who maintain that the hydroponic germs constitute rich sources of bioactive enzymes and contain an essential ingredient: the herb gist that boosts the performance of cattle. Tudor et al., (2003) assert that lamb's daily increase in weight resulting from the consumption of barley germs maybe attributed to a high microbial activity at the rumen level. Other researchers similarly remark that the gist factor present in maize hydroponic fodder boosts the performance of birds and animals up to $8 \%$. Thus, the study undertaken by Bari et al., (2020) shows an improvement in growth performance through the use of hydroponic green forage in lamb feed. Therefore, it is recommended that local farmers use hydroponic barley as an alternative forage for lambs and other livestock.The 
research work (Bari et al., 2019) shows that innovation negatively influences the financial structure and has no influence on financial performance. This data is explained by the age of the project (only 2 years of experience) during which companies often have high financial needs.It should be noted that the cooperative has an encouraging financial and commercial profitability, despite unfavorable economic conditions.

Our result look similar to those observed by Gebremedhin, (2015) who showed that the hydroponic barley aliment increases the total absorption of the dry material, aliment conversion efficiency as well as physical weight increase in comparison with growing goats' concentrated regimes. Fayed, (2011) analogous results when he asserts that the addition of hydroponic barley to the daily intake boosts the growth performances of lambs. Another study conducted by Eshtayeh, (2004) ascribes this positive tendency of growth to better dairy results to the incorporation of hydroponic barley and to the consumption of olive pomace especially in milky race of Awessi of Jordan. In this respect, Ata et al., (2016) underscore the benefits of the incorporation of FVH when feeding lambs.

\section{CONCLUSION}

The resort to hydroponic barley as a fodder complement allows for a performance improvement in goat cattle while preserving the Argan fields and ensures a rationing of exploitation. We maintain that this fodder can prove to be fulfilling and craved by animals. Therefore, we observe that the growth performances are realized faster following consumption of hydroponic barley by both males (up to 30\%) and females (up to 38\%) at different ages. This clearly shows that hydroponic barley asserts itself as a beneficial alternative for farmers wishing to increase and boost the performance of their goat stock.

\section{REFERENCES}

Ata M. (2016), Effect of hydroponic Barley fodder on Awassilamb'sperformance.Journal of Biology, Agriculture and Healthcare, vol.6, $n^{\circ} 8, p .60-64$.

Bari S., Hikamat A., Kaaya A., El Moukhtari A., Mannas H. (2020). Use of hydroponic green fodder in sheep meat breeding and production in the Souss Massa Region (South of Morocco): Preliminary study. International Journal of Agriculture, Environment and Bioresearch, Jan-Feb 2020, Volume 5, Issue 1, pp 329-336.

Bari I., S. Bari, A. Kaaya, H.Mannas (2019). Innovation, performance financière et entrepreneuriat coopératif: Quels liens ? Cas de la culture hydroponique de l'orge au sein de la Coopérative Ait Si Salem. International Journal of Business \& Economic Strategy (IJBES), Vol 12, pp 1-7.

Bhise V., Chavan J. et Kadam S. (1988).Effects of malting on proximate composition and in vitro protein and starch digestibilities of grain sorghum.Journal of Food Science and Technology, 25, p. 327-329.

Bourbouze A. et El Aïch A., (2005). L'élevage caprin dans l'arganeraie : l'utilisation conflictuelle d'un espace. Cahiers Agricultures vol. 14, $n^{\circ}$ 5, p. 447-453.

Bourbouze A, El Aïch A. Goat farming in the argan grove: the conflicting use of space. Agricultures Notebooks. Flight 2005;14(5):447-453. 
Carillo G. et Al. (2013).Produccion y calidadfiscicoquimica de leche de cabras suplementadas con forraje verde hidroponico de maïs.Agronomiamesoamericana, $24: 1$, ISSN : 1021-7444, p.169-176.

Cuddeford D. (1989). Hydroponic grass. In:Practice 11 (5), p. 211-214.

Chavan J. et Kadam S.S. (1989). Nutritional improvement of cereals by sprouting, Critical Reviews in Food Sciences and Nutrition, 28 (5),401-437.

El Aich A., Bourbouze A. et Morand-Fehr, (2005). La Filière du chevreau de l'arganeraie, un produit typique et durable. Annales de la Recherche Forestière au Maroc, 38, pp. 124-37.

Eshtayeh, I.F.A., (2004). A new Source of Fresh Green Feed (Hydroponic Barley) for Awass Sheep.Master Degree, Faculty of Graduate Studies, at An- Najah National University, Nablus, Palestine, p. 40.

Fayed A.M. (2011), Comparative study and feed evaluation of sprouted barley grains on rice straw Versus Tamarixmannifera on performance of growing Barki Lambs in Sinai, Journal of American Science, 7, p. 954-961.

Gebremedhin W. (2015), Nutritional benefit and economic value of feeding hydroponically grown maize and barley fodder for Konkan Kanyal goats.IOSR-JAVS, 8 (7), p. 24-30.

Lafdaili M. (2014). Contribution to the study of Production systems and morphological characterization of goat farms in the Dakhla region. Graduation project for obtaining the Diploma of State Engineer in Agronomy, Meknes; 2014.

López-Aguilar, Raúl; Murillo-Amador, Bernardo; Rodríguez-Quezada (2009). Guadalupe El forrajeverdehidropónico $(\mathrm{FVH})$ : una alternativa de producción de alimento para el ganadoen zonas áridasInterciencia, vol. 34, núm. 2, febrero, 2009, pp. 121-126.

Lorenz K. and D'appaloina B. (1989), Cereal sprouts: composition, nutritive value, food application. CRC Critical reviews in Food Science and Nutrition, 13, p. 353-385.

Ministère de l'Agriculture et de la Pêche Maritime (MAPM), (2012). Situation de l'Agriculture Marocaine, $N^{\circ} 10, \operatorname{MAPM}(E d)$, p. 206.

Ministère de l'Agriculture et de la Pêche Maritime (MAPM), (2014). Enquête d'élevage. Effectifs des bovins, ovins et caprins. Direction d'élevage, Ministère de l'Agriculture et de Pêche Maritime.

Naik P.K. et Al. (2014). Effect of feeding hydroponics maize fodder on digestibility of nutrients and milk production in lactating cows.Indian Journal of Animal Science, 84, p. 880-883.

Office de Mise en Valeur Agricole Souss Massa (ORMVA/ MS). (2015). Monographie générale de la Région Souss Massa, 2015.

Rodríguez M., C. et C., Morales (2002), Característicasnutritivasdelforraje verde hidropónicoproducidoencondiciones de invernadero y riegoporaspersión. Chihuahua Ganadero, Enero-febrero, año 4, vol. 15, Chihuahua, Chih., Mexique, p. 20.

Tudor, G., Darcy, T., Smith, P. and Shallcross, F. (2003). The intake and live weight change of drought master steers fed hydroponically grown, young sprouted Barley fodder (Auto Grass).

Department of Agriculture Western Australia. 